\title{
PENGARUH SUHU DAN LAMA EKSTRAKSI SECARA PENGUKUSAN TERHADAP RENDEMEN DAN KADAR ALBUMIN IKAN GABUS (Ophiocephalus striatus)
}

\author{
Matheus Nugroho*) \\ *) Tenaga Pengajar Universitas Yudharta Pasuruan
}

\begin{abstract}
Abstrak
Tujuan penelitian ini untuk menentukan suhu dan lama ekstraksi pengukusan yang tepat untuk mendapatkan rendemen dan kadar albumin yang optimal dari ikan gabus (Ophiocephalus striatus). Metode penelitian adalah menentukan suhu pada kisaran $40-90^{\circ} \mathrm{C}$, dan ekstraksi secara pengukusan waterbath selama 25-35 menit, untuk mendapatkan rendemen dan kadar albumin ekstrak kasar ikan gabus yang optimal. Pengujian suhu dan lama ekstraksi secara pengukusan terhadap rendemen, kadar albumin dan rendemen albumin daging ikan gabus menggunakan analisa Rancangan Acak Kelompok Faktorial (RAKF). Hasil penelitian menunjukkan bahwa tidak ditemukan interaksi antara berbagai faktor perlakuan dengan semakin tinggi suhu kisaran $40-90^{\circ} \mathrm{C}$, dan lama pengukusan kisaran 25-35 menit. Rendemen albumin tertinggi ekstrak ikan gabus sebesar $2,459 \mathrm{~g} / 100 \mathrm{~g}$, oleh suhu pengukusan $60^{\circ} \mathrm{C}$ selama $25-35$ menit.
\end{abstract}

Kata kunci : ikan gabus (Ophiocephalus striatus), suhu dan lama ekstraksi pengukusan, rendemen albumin

\begin{abstract}
The objective of this study to determine the temperature and duration of the steaming extraction that right to obtain albumin content and yield that optimal from the fish Gabus (Ophiocephalus striatus). The research method is to determine the temperature in the range $40-90^{\circ} \mathrm{C}$, and the steaming extraction waterbath for 25-35 minutes, to obtain yield and albumin content of fish Gabus coarse extract that optimal. Testing temperature and extraction time is steaming toward yield, albumin content and albumin yield of fish Gabus meat using Group Randomized Factorial design analysis (RAKF). The results showed that no interaction between the various factors treated with the higher temperature range $40-90^{\circ} \mathrm{C}$, and the range of $25-35$ minutes longer steaming. The highest albumin yield extract of the common snakehead of $2.459 \mathrm{~g} / 100 \mathrm{~g}$ fish, by steaming temperature $60^{\circ} \mathrm{C}$ for $25-35$ minutes
\end{abstract}

Key words: fish Gabus (Ophiocephalus striatus), extraction temperature and duration of steaming, the albumin yield 
Salah satu protein sederhana dalam plasma darah adalah albumin. Albumin dalam tubuh disintesa di dalam hati dengan jumlah sangat kecil. Kekurangan albumin dalam serum dapat mempengaruhi pengikatan dan pengangkutan senyawa-senyawa endogen dan eksoden, termasuk obat-obatan, karena seperti diperkirakan distribusi obat keseluruh tubuh itu pengikatannya melalui fraksi albumin (Goldstein et al., 1968; Vallner, 1977; Tandra et al., 1988). Jika kadar albumin serum beradadibawah nilai normal, maka fraksi obat yang terikat protein tersebut berkurang, dengan kata lain fraksi obat bebas banyak sehingga keadaan ini dapat menimbulkan pengaruh obat yang tidak diinginkan.

Pengadaan albumin terutama untuk kasus bedah saat ini mencapai 91\%, 2/3 albumin tersebut dipakai di bagian bedah dan sisanya $1 / 3$ bagian dipergunakan untuk penanganan penyakit dalam. Albumin merupakan komoditi impor, pada masa sebelum krisis moneter, harga infus albumin berkisar Rp. 250.000,- sampai dengan Rp. 300.000,-. Pada saat kurs dollar terhadap nilai rupiah meningkat hampir empat kali, harga serum albumin untuk infus mencapai $\mathrm{Rp}$. 1.100.000,- sampai dengan Rp. 1.300.000,- per botol kemasan 100 ml-20\% albumin (Alexander et al., 1979; Tullis, 1997).

Uji coba telah dilakukan oleh instalasi gizi dan bagian bedah RSUD. Dr. Syaiful Anwar Malang selama 1979-1998, berupa pemberian filtrat dari $2 \mathrm{~kg} / \mathrm{hari}$ ikan gabus terhadap pasien pasca operasi, ibu yang baru melahirka dan beberapa pasien luka tusukan, yang mempunyai kadar albumin rendah $(2,8 \mathrm{~g} / \mathrm{dl})$, selama $2-4$ hari terjadi peningkatan albumin tubuh menjadi 4,4-5,5 g/dl (kadar albumin normal tubuh manusia), dan permukaan luka mengalami penutupan. Proses pengukusan tersebut dilakukan pada suhu air mendidih (Soemarko, 1997).

Pengaruh perlakuan suhu tinggi menyebabkan perubahan melemahnya enzim proteinase dan nilai daya cerna protein (Nielsen $e t$ al., 1988; Deshpande and Damodaran, 1989 dalam Folawiyo and Apenten, 1996). Menurut Stryer (1968), Slavik (1982) dan Arakawa et al. (1991) dalam Folawiyo and Apenten (1996), menjelaskan bahwa perlakuan panas pada albumin akan menghasilkan perubahan struktur yang tidak dapat balik 
(irreversible), yang terlihat dengan meningkatnya protein yang tidak larut dalam air. Pengaruh perlakuan panas pada struktur albumin juga dapat albumin, sehingga diperlukan panas yang tepat pada struktur protein tersebut (Stryer, 1968; Slavik, 1982; Arakawa et al., 1991; Wicker et al., 1986 dan Arntfield et al., 1989 dalam Folawiyo and Apenten, 1996).

Berdasarkan hasil penelitian pada ikan gabus dan ikan tomang didapatkan kadar albumin sebesar $1332,7 \mathrm{mg} / 100 \mathrm{~g}$ dan 1188,05 mg/100 g (Carvallo, 1998). Analisa kadar albumin pada filtrat ikan gabus hasil pengukusan suhu $98^{\circ} \mathrm{C}$ adalah 19,4\% (Martini, 1998). Hasil analisa sterilisasi ikan gabus pada suhu $121^{\circ} \mathrm{C}$ selama 25 menit didapatkan kadar albumin filtrat adalah $116,419 \pm 22,660 \mathrm{mg} / 100 \mathrm{~g}$ (Hidayati, 1999). Hal ini semua memperkuat alasan untuk memperoleh isolat albumin hasil ekstraksi secara pengukusan ikan gabus sebagai pengganti serum albumin impor dalam upaya membantu mempertahankan dan meningkatkan nilai gizi dan kesehatan manusia, sehingga dapat mengurangi anggaran biaya kesehatan yang makin mahal.

\section{MATERI DAN METODE}

Peralatan yang dipergunakan pembuatan ekstrak kasar ikan gabus antara lain : pisau, gunting, waterbath, thermokopel, thermometer $100^{\circ} \mathrm{C}$, timbangan gelas ukur, kain saring, plastik dan press hidrolik. Peralatan untuk analisa kadar albumin antara lain : kuvet diameter $1 \mathrm{~cm}$, Shimadzu spectrophotometer UV-100-02 dan spectrophotometer

SMA autoanalyzer.

Bahan-bahan yang digunakan untuk ekstraksi adalah ikan gabus yang diperoleh dari bendungan Karangkates dalam keadaan hidup dan aquadest. Bahan untuk uji kadar albumin menggunakan metode brom cresol green adalah buffer succinate (7 mmol/l $\mathrm{pH} 4,2$ ), brom cresol green $0,15 \mathrm{mmol} / \mathrm{l}$, brij 35 dan aquadest dapar succinate (0,01 M; pH 4,2), untuk kadar albumin setelah pemurnian kolom filtrasi gel pengujiannya dengan UV, bahannya antara lain BSA standar $0,5 \mathrm{~g} / \mathrm{l}$, buffer phosphat 0,1 $\mathrm{M} \mathrm{pH} \mathrm{7,1} \mathrm{dan} \mathrm{aquadest.}$

Prosedur penelitian ini meliputi : ekstraksi ikan gabus secara pengukusan waterbath (Modifikasi Sajdok et al., 1989) dan penentuan kadar albumin 
(Doumas; Watson and Biggs, ikat daging mengkerut dan 1971).

berkurang volumenya, sehingga air

Analisa data yang digunakan dalam pengujian pengaruh suhu dan lama ekstraksi secara pengukusan terhadap rendemen, kadar albumin dan rendemen albumin ikan gabus menggunakan analisa Rancangan Acak Kelompok (RAKF).

\section{HASIL DAN PEMBAHASAN}

Hasil pengamatan Tabel 1. Menunjukkan bahwa semakin tinggi suhu dan lama pengukusan waterbath, pada kisaran suhu 40$90^{\circ} \mathrm{C}$ dengan lama 25-35 menit menghasilkan rerata rendemen ekstrak kasar semakin besar. Kenaikan ini diduga berkaitan dengan menurunnya rehidrasi jaringan ikat daging ikan gabus, sebagai akibat meningkatnya suhu dan lama pengukusan. Pada kondisi rehidrasi menurun kondisi kemampuan daging menahan air hilang, karena ruang antar jaringan dalam daging menguap dan keluar sebagai cairan. Rustad and Nesse (1983) melaporkan bahwa nilai rehydration index cenderung menurun pada perlakuan pemanasan antara $30-75^{\circ} \mathrm{C}$ dengan lama 5-30 menit. Suhu pemanasan $30^{\circ} \mathrm{C}$ dengan lama 5 menit mempunyai rehydration index paling tinggi, sedangkan suhu pemanasan $75^{\circ} \mathrm{C}$ dengan lama 30 menit mempunyai rehydration index paling rendah. Penurunan tersebut berlanjut sampai dengan suhu pemanasan $90^{\circ} \mathrm{C}$.

Hasil analisa ragam menunjukkan bahwa kombinasi perlakuan suhu dan lama pengukusan waterbath interaksinya tidak berpengaruh nyata, tetapi mandirinya berpengaruh sangat nyata terhadap rendemen ekstrak kasar ikan gabus. 
Jurnal Teknologi Pangan Vol.3 No.1

Juni 2012

Tabel 1. Rendemen ekstrak kasar karena pengaruh perlakuan suhu dan lama ekstraksi pengukusan waterbath

\begin{tabular}{|c|c|}
\hline Suhu pengukusan waterbath $\left({ }^{\mathbf{}} \mathbf{C}\right)$ & Rendemen $(\boldsymbol{\%})$ \\
\hline 40 & $13,1 \mathrm{a}$ \\
\hline 50 & $13,9 \mathrm{a}$ \\
\hline 60 & $20,3 \mathrm{c}$ \\
\hline 70 & $17,5 \mathrm{~b}$ \\
\hline 80 & $21,1 \mathrm{~cd}$ \\
\hline 90 & $22,9 \mathrm{~d}$ \\
\hline BNT $(\alpha=0,01)$ & 3,663 \\
\hline Lama pengukusan (menit) & Rendemen (\%) \\
\hline 25 & $14,7 \mathrm{a}$ \\
\hline 30 & $19,2 \mathrm{ab}$ \\
\hline 35 & $20,6 \mathrm{~b}$ \\
\hline BNT $(\alpha=0,01)$ & 5,182 \\
\hline
\end{tabular}

Keterangan : angka rendemen yang diikuti dengan huruf yang sama pada kolom yang sama tidak berbeda nyata pada uji BNT $(\alpha=$ 0,01 )

Hasil uji BNT $(\alpha=0,01)$ menunjukan bahwa perlakuan suhu pengukusan waterbath $90^{\circ} \mathrm{C}$ (suhu daging $66^{\circ} \mathrm{C}$ ) memberikan nilai rendemen ekstrak kasar tertinggi yaitu $22,9 \%$. Hal ini diduga karena jaringan ikat daging ikan relatif porous dan membentuk agreggat, sehingga kemampuan rehidrasi dari jaringan $\mathrm{n}$ ikat menurun, pada kondisi tersebut dapat mempermudah proses pemisahan cairan saat pengepresan. Irianto et al. (1986) menjelaskan bahwa pemanasan menciptakan struktur yang porous, karena ikatan protein akan saling memisah dan membentuk agreggat, sehingga mempermudah pemisahan cairan saat pengepresan.

Waktu optimal untuk menghasilkan rendemen ekstrak kasar tertinggi adalah 35 menit dengan nilai rendemen sebesar 20,6\%. Hal tersebut diduga pada lama pengukusan 35 menit kisaran 
suhu $40-90^{\circ} \mathrm{C}$, telah menyebabkan kemampuan menahan air dari daging ikan menurun, ruang antar serabut urat daging ikan gabus menjadi porous, sehingga cairan sel yang terikat dalam jaringan keluar. Rustad and Nesse menyatakan bahwa permulaan menurunnya kemampuan menahan air daging capelin yang dicincang terjadi pada lama pemanasan 5-30 menit, dengan kisaran suhu 30$35^{\circ} \mathrm{C}$. Lama pemanasan 30 menit mempunyai water holding capacity lebih rendah dibandingkan lama pemanasan 5 menit.

Berdasarkan hasil analisa kadar albumin ekstrak kasar ikan gabus menunjukan, bahwa semakin tinggi suhu dan lama pengukusan dengan waterbath suhu $40-90^{\circ} \mathrm{C}$ dan waktu pengukusan 25-35 menit, menghasilkan kadar albumin semakin rendah. Folawiyo and Apenten (1996) menyatakan bahwa pemanasan daging suhu $90^{\circ} \mathrm{C}$, selama 20 menit menyebabkan struktur albumin irreversible, hal itu ditandai dengan meningkatnya permukaan protein non polar, dan perubahan sifat fungsionalnya. Foegeding et al. (1986) menyatakan, bahwa pada suhu $95^{\circ}$, unit ikatan yang terbentuk cukup banyak, dan protein tidak lagi terdispersi sebagai koloid, tetapi albumin mengalami koagulasi dan mengarah terjadinya denaturasi.

Hasil uji BNT $(\alpha=0,01)$ menunjukan bahwa kadar albumin ekstrak kasar tertinggi adalah 145,7 $\mathrm{mg} / \mathrm{g}$, hasil perlakuan suhu pengukusan waterbath $40^{\circ} \mathrm{C}$ (suhu daging $36^{\circ} \mathrm{C}$ ). Kadar albumin tinggi, diduga karena kelarutan albumin dalam ekstrak kasar ikan gabus belum mengalami kerusakan, secara visual tampak kekeruhan ekstrak kasar belum meningkat, larutan berwarna jernih kemerahan, partikel-partikel ekstrak tidak mengendap meskipun dibiarkan, dan masih dapat menimbulkan ketegangan pada larutan ekstrak tersebut. Winarno menyatakan, bahwa larutan protein yang mengalami kerusakan sebagai akibat pemanasan, larutan protein tidak lagi terdispersi sebagai koloid, dan partikel-partikel tersebut cenderung terpisah dan mengendap ketika didiamkan. 
Jurnal Teknologi Pangan Vol.3 No.1

Juni 2012

Tabel 2. Kadar albumin ekstrak kasar ikan gabus karena pengaruh perlakuan suhu dan lama ekstraksi pengukusan waterbath

\begin{tabular}{|c|c|}
\hline Suhu pengukusan waterbath $\left.^{\mathbf{0}} \mathbf{C}\right)$ & Kadar Albumin $(\mathbf{m g} / \mathbf{g})$ \\
\hline 40 & $145,7 \mathrm{c}$ \\
\hline 50 & $130,2 \mathrm{c}$ \\
\hline 60 & $119,5 \mathrm{bc}$ \\
\hline 70 & $122,5 \mathrm{c}$ \\
\hline 80 & $84,2 \mathrm{a}$ \\
\hline 90 & $59,8 \mathrm{a}$ \\
\hline BNT $(\alpha=0,01)$ & 27,816 \\
\hline Lama pengukusan (menit) & Kadar Albumin (mg/g) \\
\hline 25 & 124,6 \\
\hline 30 & 104,7 \\
\hline 35 & 101,7 \\
\hline BNT $(\alpha=0,01)$ & 39,337 \\
\hline
\end{tabular}

Keterangan : angka kadar albumin yang diikuti dengan huruf yang sama pada kolom yang sama tidak berbeda nyata pada uji BNT ( $\alpha=$ $0,01)$

Lama pengukusan optimum untuk menghasilkan kadar albumin ekstrak kasar tertinggi adalah 25 menit, dengan kadar albumin sebesar $124 \mathrm{mg} / \mathrm{g}$. Rustad and Neese (1983) menyatakan, bahwa ekstrak protein daging ikan cincangan cenderung meningkat kadarnya ketika dilakukan pemanasan pada suhu $30-40^{\circ} \mathrm{C}$, dengan lama pemanasan 5-10 menit, selanjutnya jika lama pemanasan 10-30 menit, maka kadar ekstrak proteinnya cenderung terjadi penurunan.

Berdasarkan hasil analisa menunjukan bahwa semakin menurun suhu pengukusan waterbath kisaran suhu $40-90^{\circ} \mathrm{C}$, dengan lama pengukusan 25-35 menit, maka rendemen albumin daging semakin menurun. Rustad and Nesse (1983) menjelaskan hasil penelitiannya bahwa turunnya rehidrasi dan ekstrak protein semakin meningkat dengan 
meningkatnya suhu dan lama terkait dengan kondisi daging ikan pemanasan, pada kisaran suhu 30- gabus belum mengalami agreggat $80^{\circ} \mathrm{C}$, dengan lama pemanasan 5-30 secara keseluruhan, karena proses menit. Hasil analisa ragam menunjukan bahwa kombinasi perlakuan suhu dan lama pengukusan, interaksinya tidak berpengaruh nyata, begitu juga dengan lama pengukusan, hanya perlakuan suhu pengukusan yang memberikan pengaruh nyata.

Hasil uji BNT $(\alpha=0,05)$ menunjukan bahwa rendemen albumin daging ikan gabus optimal adalah 2,459 g/100 g, dengan perlakuan suhu pengukusan waterbath $60^{\circ} \mathrm{C}$ (suhu daging $45^{\circ} \mathrm{C}$ ). Optimalnya rendemen albumin tersebut, pada prinsipnya radiasi panas antar jaringan daging belumlah merata saat pengukusan waterbath suhu $60^{\circ} \mathrm{C}$. Jaringan serabut urat daging ikan gabus belum mengkerut, kadar air dan rehidrasi belum turun, sehingga cairan sel yang keluar dari daging ikan gabus dan kandungan proteinnya masih kompleks dan tinggi. Raeker and Johnson (1995), menunjukan bahwa permulaan denaturasi albumin plasma darah pada suhu $(69,1 \pm 0,2)^{\circ} \mathrm{C}$. Shimada and Matsushita (1981) melaporkan, bahwa agreggat daging mulai berkembang suhu $60-65^{\circ} \mathrm{C}$. 
Jurnal Teknologi Pangan Vol.3 No.1

Juni 2012

Tabel 3. Rendemen albumin daging ikan gabus pengaruh perlakuan suhu dan lama ekstraksi pengukusan waterbath

\begin{tabular}{|c|c|}
\hline Suhu pengukusan waterbath $\left({ }^{\mathbf{} C)}\right.$ & Rendemen Albumin (g/100g) \\
\hline 40 & $1,917 \mathrm{~b}$ \\
\hline 50 & $1,847 \mathrm{~b}$ \\
\hline 60 & $2,459 \mathrm{c}$ \\
\hline 70 & $2,049 \mathrm{~b}$ \\
\hline 80 & $1,714 \mathrm{~b}$ \\
\hline 90 & $1,289 \mathrm{a}$ \\
\hline BNT $(\alpha=0,05)$ & 0,403 \\
\hline Lama pengukusan (menit) & Rendemen Albumin (g/100g) \\
\hline 25 & 1,791 \\
\hline 30 & 1,889 \\
\hline 35 & 0,570 \\
\hline BNT $(\alpha=0,05)$ & \\
\hline
\end{tabular}

Keterangan : angka rendemen albumin yang diikuti dengan huruf yang sama pada kolom yang sama tidak berbeda nyata pada uji BNT $(\alpha=$ $0,05)$

Raeker and Johnson (1995), menunjukan bahwa permulaan denaturasi albumin plasma darah pada suhu $(69,1 \pm 0,2)^{\circ} \mathrm{C}$. Shimada and Matsushita (1981) melaporkan, bahwa agreggat daging mulai berkembang suhu $60-65^{\circ} \mathrm{C}$.

Lama waktu pengukusan optimum, dengan nilai rendemen albumin daging ikan gabus tertinggi $1,959 \mathrm{~g} / 100 \mathrm{~g}$ adalah 35 menit. Nilai tersebut ternyata tidak berbeda nyata dengan lama pengukusan 25 dan 30 menit. Tidak berbeda nyata tersebut diduga pada kisaran lama pengukusan waterbath 25-35 menit rendemen albumin daging ikan gabus yang dihasilkan relatif sama. Rustad and Nesse (1983) menyatakan bahwa lama pemanasan 30-35 menit, akan menurunkan rehidrasi daging, dan cairan daging mudah keluar, namun pada kisaran lama pemanasan tersebut terjadi penurunan kadar protein. 
Kesimpulan

Hasil penelitian menunjukkan bahwa tidak ditemukan interaksi antara berbagai faktor perlakuan dengan semakin tinggi suhu kisaran $40-90^{\circ} \mathrm{C}$, dan lama pengukusan kisaran 25-35 menit. Rendemen albumin tertinggi ekstrak ikan gabus sebesar $2,459 \mathrm{~g} / 100 \mathrm{~g}$, oleh suhu pengukusan $60^{\circ} \mathrm{C}$ selama $25-$ 35 menit.

\section{Saran}

Berdasarkan hasil penelitian tersebut diatas, diharapkan dilakukan penelitian lanjutan mengenai pemurnian albumin dan penentuan berat molekul dari ekstraksi secara pengukusan rendemen dan kadar albumin yang paling optimal.

\section{Daftar Pustaka}

Alexander, M.R.; Ambre, J.J.; Liskon, B.I. and D.C. Trash, 1979. Therapeutic Use Of Albumin. JAMA., 241 : 2527-2529.

Arntfield, S. D.; Murray, E. D. and M. A. H. Ismond, 1986. Effect of Salt on the Thermal Stability of Storage Proteins from Fababean (Vice faba). J. Food Sci., 51 : 371-377.
Carvallo, Y. N., 1998. Study Profit Asam Amino, Albumin, Mineral Zn pada Ikan Gabus (Ophiocephalus sriatus) dan Ikan Tomang (Ophiocephalus

Micropeltus). Fakultas Perikanan. Universitas Brawijaya. Malang. Hal 2830.

Doumas, B.T.; Watson, W.A. and H.G. Biggs, 1971. Albumin Standard and The Measurement of Serum Albumin with Brom Cresol Green. J. Clin Chim Acta., $31: 87$.

Foegeding, E. A.; Allen, C. E. and W. R. Dayton, 1986. Effect of Heating Rate on Thermally Formed Myosin, Fibrinogen and Albumin Gels. J. Food Sci., 51 : 104107.

Folawiyo, Y. L. and O. R. K. Apenten, 1996. The Effect of Heat Acid Treatment on The Structure of Rapeseed Albumin (Napin). J. Food Sci., 61 : 237-239.

Goldstein, A.; Aronow, L. and S. M. Kalman, 1968. Principles 
of Drug Action-The Basis of Pharmacology. New York. Page, 45-112.

Hidayati, O., 1999. Study Kadar Albumin, Zn dan TVB Filtrat Ikan Gabus (Ophiocephalus sriatus) pada Lama Sterilisasi dan Penyimpanan

Berbeda. yang

Penelitian. Laporan Perikanan. Fakultas Brawijaya. Malang. Hal 36.

Irianto, H. E.; Suryaningrum, T. D.; Suparno dan Muljanah, 1995. Penghambatan

Pembusukan "Press Liquor" dari Pengolahan Tepung Ikan dengan Perlakuan Asam Formiat dan Pemanasan. Jurnal Penelitian Perikanan Indonesia., I : 1-5.

Martini, N. D., 1998. Pengaruh Lama Pengukusan Terhadap Kandungan Albumin, Asam Amino dan Zn pada Ikan Gabus (Ophiocephalus sriatus). Laporan Penelitian. Fakultas Perikanan. Universitas Brawijaya. Malang. Hal. 36.
Raeker, M.O. and Johnson, 1985. Thermal and Function Properties of Bovine Blood Plasma and Egg White Protein. J. Food Sci., 60 : 687.

Rustad, T. and N. Nesse, 1983. Heat Treatment and Drying Capelin Mince, Effect on Water Binding and Soluble Protein. J. Food Sci., 48 : 1320-1347.

Sadjok, J.; Pozarkova, D.; Rauch, P. and J. Kas, 1989. Thermal Denaturation of Hen Egg White Studied by Chromatographic and Immunochemical

Techniques. J. Food Sci., 54 : 906-908.

Shimada, K. and S. Matsushita, 1981. Effect of Salts and Denaturations on Thermocoagulation of Proteins. J. Agric Food Chem., $29: 15$.

Soemarko, 1997. Pengaruh Diet Ikan Kutuk dan Telur Terhadap Peningkatan Albumin dan Penutupan Luka Operasi. Rumah Sakit 
Dr. Saiful Anwar. Malang. Vallner, J. J., 1977. Binding of Hal 1-28.

Drugs By Albumin and Plasma Protein. J. Pharm

Tandra, H.; Soemartono, H.W. dan Sci., 66 ; 447-449.

A. Tjokroprawiro, 1988. Metabolisme dan Aspek Klinik Albumin. J. Med., 3 : 249-258.

Tullis, J. L., 1997. Albumin 2 Guidelines for Clinical Use. JAMA., 237 : 460-463. 